\title{
Genotypic characterization of Indian isolates of infectious bursal disease virus strains by reverse transcription-polymerase chain reaction combined with restriction fragment length polymorphism analysis
}

\author{
C. V. PRIYADHARSINI' ${ }^{1}$, T. M. A. SENTHILKUMAR ${ }^{1 *}$, P. RAJA ${ }^{1}$, K. KUMANAN ${ }^{2}$ \\ ${ }^{1}$ Department of Animal Biotechnology, Madras Veterinary College, Chennai-600007, India; \\ ${ }^{2}$ Dean, Faculty of Basic Sciences, Madras Veterinary College, Chennai-600007, India
}

Received March 24, 2015; revised July 2, 2015; accepted February 1, 2016

\begin{abstract}
Summary. - The reverse transcription PCR (RT-PCR) combined with restriction fragment length polymorphism (RFLP) is used for the differentiation of classical virulent (cv), virulent (v) and very virulent (vv) strains of infectious bursal disease virus (IBDV) isolates from chicken bursal tissues in southern states of India. In the present study, six different isolates (MB11, HY12, PY12, BGE14, VCN14 and NKL14) of IBDV strains were subjected for genotyping along with vaccine virus (Georgia, intermediate strain) using RT-PCR for amplification of a 743 bp sequence in the hypervariable region of VP2 gene followed by restriction enzyme digestion with 5 different restriction enzymes (BspMI, SacI, HhaI, StuI and SspI). The RT-PCR products obtained from vvIBDV strains were digested by SspI enzyme except PY12, BGE14 and MB11 isolates. The SacI digested the isolate MB11, PY12 and the vaccine strain, but it did not cleave the very virulent isolates of IBDV. HhaI cleaved all the isolates with different restriction profile patterns. StuI digested all the vvIBDV isolates and BspMI was not able to differentiate field isolates from vaccine strain. Though RT-PCR combined with RFLP is a genotypic method, further confirmation of serotypes to distinguish the vvIBDV from cvIBDV has to be carried out using pathogenicity studies.
\end{abstract}

Keywords: infectious bursal disease virus; reverse transcription polymerase chain reaction; restriction fragment length polymorphism; VP2 gene; genotyping

\section{Introduction}

Infectious bursal disease (IBD), a highly contagious disease of poultry industry is caused by infectious bursal disease virus (IBDV) belonging to the genus Avibirnavirus. The acute form of this disease occurs during the age of 3-6 weeks (Kibenge et al., 1988; Balamurugan and Kataria, 2006). IBDV replicates in the lymphocytes of the bursa of Fabricius and

“Corresponding author. E-mail: tmaskumar@yahoo.com, tmaskumar@tanuvas.org.in; phone: +91-44-25369301.

Abbreviations: RT-PCR $=$ reverse transcription PCR; RFLP $=$ restriction fragment length polymorphism; cvIBDV = classical virulent infectious bursal disease virus; vvIBDV = very virulent infectious bursal disease virus causes immunosuppressive disease that may cause death or impaired growth in young chickens. Although IBDV persists in chickens for a short period of time, the lesions in the bursa can last for at least 10 weeks resulting in immunosuppression of infected chickens (Winterfield et al., 1972).

Members of the Birnaviridae family are characterized by a double stranded RNA (dsRNA) genome consisting of 2 segments, A and B (Delmas et al., 2005). Smaller genomic segment B (approximately $2.9 \mathrm{~kb}$ ) encodes VP1 while the larger genomic segment A (approximately $3.3 \mathrm{~kb}$ ) encodes a $109 \mathrm{~K}$ precursor polyprotein in which the viral polypeptides are arranged in the order N-VP2-VP4-VP3-C. The structural proteins VP2 and VP3 form the outer and inner capsid of the virus (Caston et al., 2001). The antigenic sites responsible for the induction of neutralizing antibodies are highly conformation dependent and located on VP2 (Becht 
et al., 1988). The VP2 gene of IBDV contains variable region which suggests the potential differentiation of IBDV strains. The outcome of an IBDV infection largely depends on the strain and the amount of infecting viruses, the age and the breed of the bird, the route of inoculation and the presence or absence of neutralizing antibodies (Muller et al., 2003).

Reverse transcription PCR (RT-PCR) is a molecular tool frequently applied in IBDV diagnostics. Most of the RT-PCR protocols are based on VP2 nucleotide sequences. RT-PCR followed by digestion with multiple restriction enzymes (RE) or restriction fragment length polymorphism (RFLP) and nucleotide sequencing of VP2 gene have been used for differentiation of IBDV strains (Dybing and Jackwood, 1996; Jackwood and Nielsen, 1997; Ture et al., 1998). Amplification of VP2 gene of IBDV and linking genetic variations found in this region with antigenic variation have been the major focus for strain identification in recent years.

In the present study, restriction fragment profiles of partial genomic segment A of six IBDV isolates (MB11, HY12, PY12, BGE14, VCN14 and NKL14) obtained from various outbreaks in southern states of India were determined in order to establish a genetic relationship for these viruses and also to assess their strain virulence type. Five restriction enzymes (StuI, SspI, BspMI, HhaI and SacI) were included for the differentiation of the Indian IBDV isolates and identifying them as virulent, very virulent or classical strain.

\section{Materials and Methods}

Bursal tissue samples were collected from suspected outbreaks of IBD in various poultry farms in southern states of India and six IBDV isolates (MB11, HY12, PY12, BGE14, VCN14 and NKL14) were obtained from different places such as Tamil Nadu, Andhra Pradesh, Karnataka and Pondicherry. RNA extraction from all the six IBDV isolates and the vaccine strain (Georgia intermediate) as control, was carried out using Trizol reagent (RNA isoplus,
Table 1. List of restriction enzymes and their restriction activity in differentiation of IBDV isolates

\begin{tabular}{lccc}
\hline \multirow{2}{*}{$\begin{array}{l}\text { Restriction } \\
\text { enzyme }\end{array}$} & $\begin{array}{l}\text { Presence of restriction sites (activity) } \\
\text { virulent }\end{array}$ & $\begin{array}{c}\text { Vaccine } \\
\text { (Georgia intermediate) }\end{array}$ & Very virulent \\
\cline { 2 - 4 } HhaI & + & + & + \\
\hline SacI & + & + & - \\
\hline$S t u \mathrm{I}$ & - & - & + \\
\hline
\end{tabular}

$(+)=$ the partial VP2 gene of IBDV isolates are digested by restriction enzymes; $(-)=$ the partial VP2 gene of IBDV isolates are not digested.

Takara). The extracted RNA was subjected to synthesis of cDNA using commercial cDNA synthesis kit (RevertAid first strand $\mathrm{H}$ - cDNA synthesis, Thermoscientific, USA) according to manufacturer's instructions.

The VP2 gene hypervariable region (Bayliss et al., 1990) of 743 bp was amplified using the primers 743-FP-(5'-GCCCAGAGT CTACACCAT-3') and 743-RP-(5'-CCCGGATTATGTCTTTGA-3') (Jackwood and Sommer-Wagner, 2005). The reaction was carried out in a thermalcycler (Veriti, Applied Biosystems) with initial denaturation of $94^{\circ} \mathrm{C}$ for $2 \mathrm{~min}$, followed by 30 cycles of $94^{\circ} \mathrm{C}$ for $1.5 \mathrm{~min}, 53^{\circ} \mathrm{C}$ for $1 \mathrm{~min}, 72^{\circ} \mathrm{C}$ for $1 \mathrm{~min}$ and a final extension at $72^{\circ} \mathrm{C}$ for $5 \mathrm{~min}$. The PCR amplified products were purified using a PCR purification kit (Bio Basic Inc, Canada) and digested with the restriction enzymes (BspMI, SacI, HhaI, StuI, and SspI) (Table 1) according to the manufacturer's instructions (New England Biolabs, UK).

\section{Results and Discussion}

Bursal tissue samples were subjected to RNA and RTPCR amplification of variable region of VP2 gene of IBDV using specific primers with vaccine as positive control. The
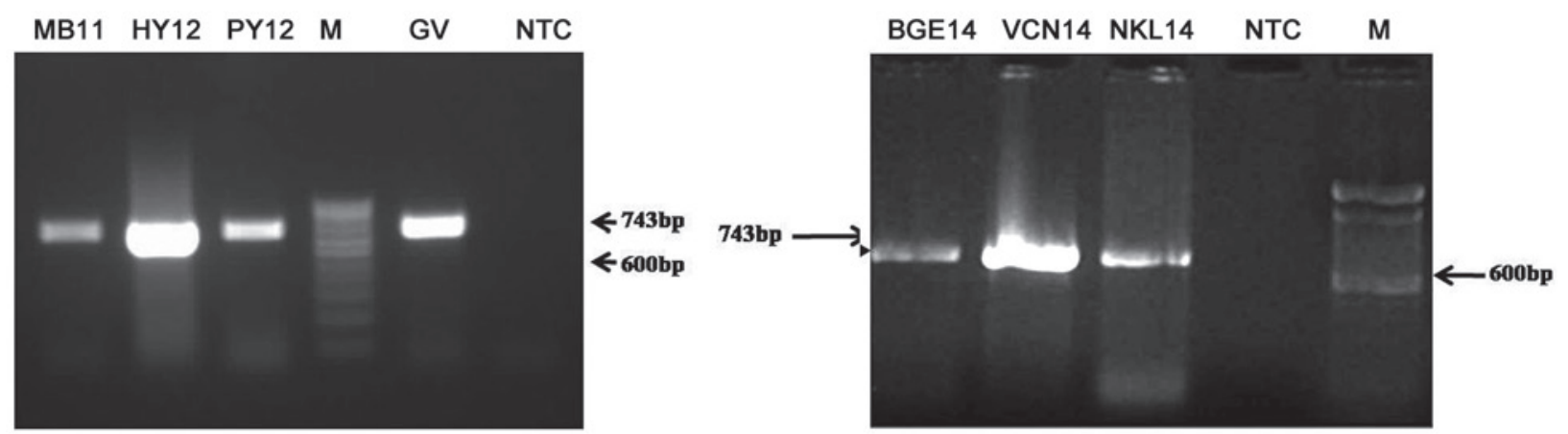

Fig. 1

RT-PCR amplification of 743 bp variable region in VP2 gene 

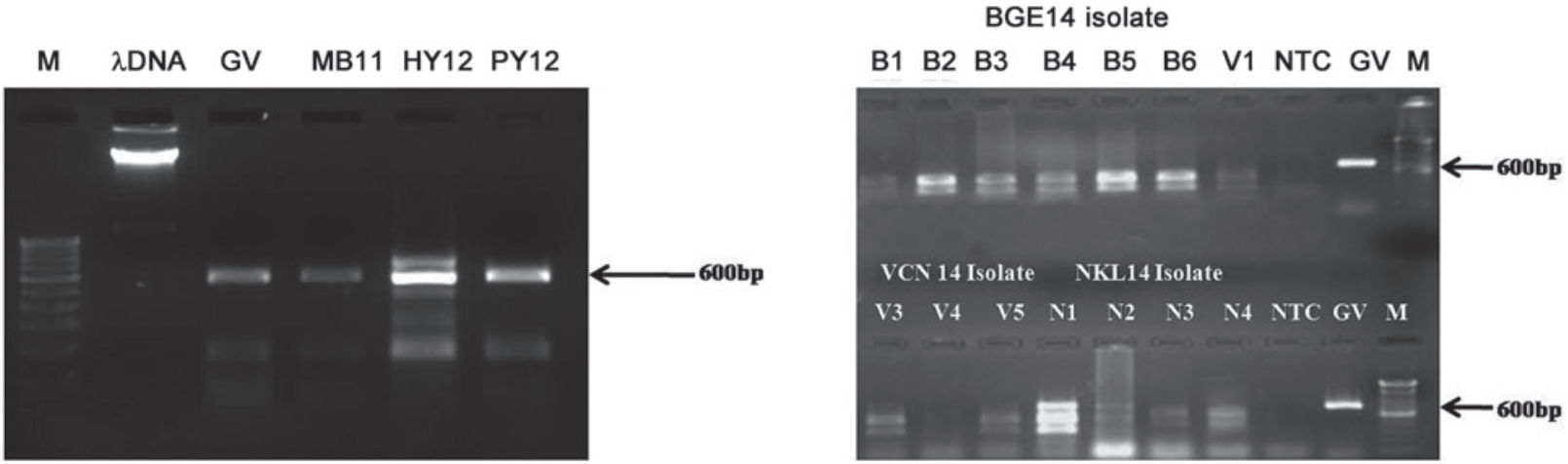

Fig. 2

HhaI digestion of RT-PCR amplified product of VP2 gene

The restriction profile of MB11 and PY12 isolates were similar to the vaccine strain (GV), and the isolates HY12, BGE14, VCN14 and NKL14 had more than one restriction site for HhaI enzyme. The restriction profile varied between different isolates.

VP2 regions of the six IBDV isolates (MB11, HY12, PY12, BGE14, VCN14 and NKL14) were amplified along with vaccine virus (Fig. 1).

The HhaI digestion of the PCR amplified products revealed the presence of restriction enzyme sites in the vaccine as well as field isolates. Though the vaccine strain and field isolates had a single restriction site for HhaI, the field isolates showed a different restriction profile pattern. The restriction profile of MB11 and PY12 isolates were similar to the vaccine strain. Whereas, the isolates HY12, BGE14, VCN14 and NKL14 had more than one RE sites for HhaI enzyme. However, the restriction profile varied between isolates (Fig. 2).

The SacI digestion with partial VP2 amplified products of MB11 and PY12 showed the presence of one RE site and the restriction profile was similar to that of vaccine strain. The other field isolates were not digested by SacI enzyme. This indicated that these isolates (HY12, BGE14, VCN14 and NKL14) are neither similar to vaccine strain (intermediate) nor classical strains of IBDV (Fig. 3). The SspI digestion of PCR amplified products showed a single RE site in HY12, VCN14 and NKL14 isolates. The SspI RE site was not observed in MB11, BGE14, PY12 and vaccine strain. The restriction profile of HY12 and VCN14 amplified products were the same and produced two different fragments. Whereas the restriction profile of NKL14 isolate was different from other isolates and had 2 restriction enzyme sites for SspI (Fig. 4).

The profile pattern with the enzyme BspMI did not show any differences between the vaccine strain and other field isolates (Fig. 5). The StuI digestion with vaccine strain, MB11 and PY12 isolates revealed the absence of RE site for this

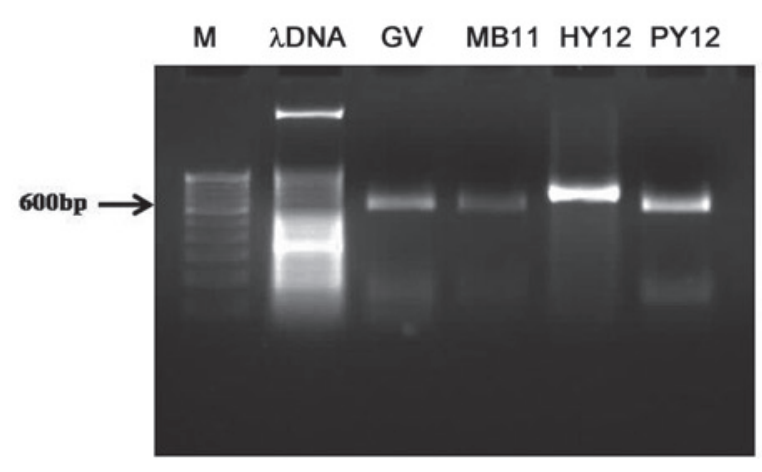

BGE14 isolate

B1 B2 B3 B4 B5 B6 V1 NTC GV M

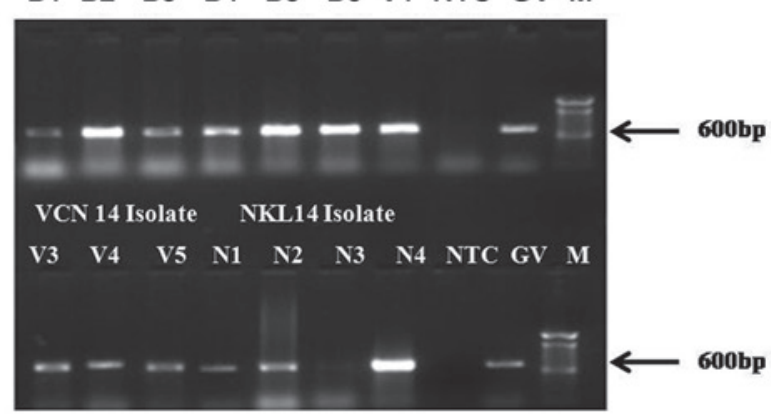

Fig. 3

SacI digestion of RT-PCR amplified product of VP2 gene

The restriction profile of MB11 and PY12 isolates showed the presence of a single restriction site and the restriction profile was similar to that of vaccine strain (GV). The other isolates were not digested by SacI enzyme. 

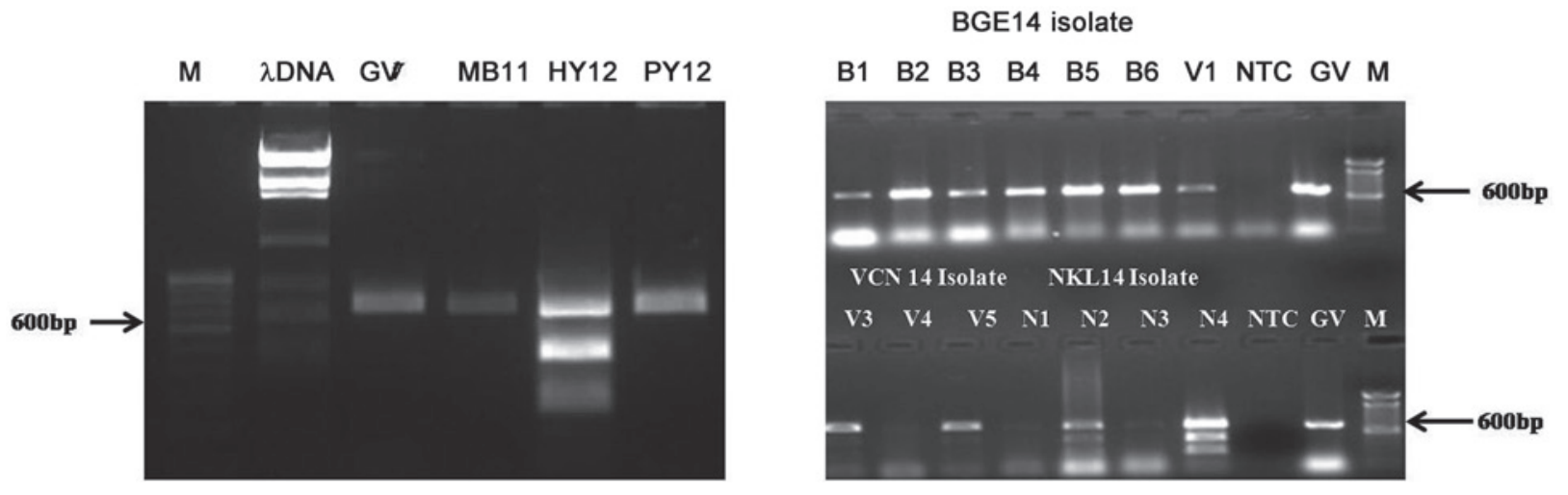

Fig. 4

SspI digestion of RT-PCR amplified product of VP2 gene

The restriction profile of HY12, VCN14 and NKL14 isolates showed the presence of a single restriction site. The SspI restriction site was not observed in MB11, BGE14, PY12 and vaccine strain (GV). The restriction profile of HY12 and VCN14 was the same and produced two different fragments. The restriction profile of NKL14 isolate had 2 restriction sites.

enzyme whereas BGE14, HY12, VCN14 and NKL14 isolates had a single site for this enzyme (Fig. 6). The restriction profile was also the same for all the very virulent field isolates.

The high mutation rate of the RNA polymerase of RNA viruses and lack of proof reading generate a genetic diversity that could lead to emergence of viruses with new properties, allowing them to persist in immune population (Lukert and Saif, 2003). Differentiation between cvIBDV and vvIBDV is very important to poultry industry with regard of choosing the appropriate vaccination programs. The application of RT-PCR combined with restriction enzymes was able to rapidly differentiate between classical and vvIBDV standard strains (Zierenberg et al., 2001). The VP2 region might be undergoing rapid genetic changes and IBD viruses were more prone for mutation thereby rendering it virulent (Adamu et al., 2013).
In the present study, the VP2 gene of IBDV isolates obtained from southern states of India was targeted to identify and to track the evolutionary changes at molecular level by nucleotide sequence analysis. The various pathotypes of the IBDV strains were determined using the presence of various restriction enzyme sites in the variable region of VP2 gene using PCR-RFLP. The results showed that four of the six field isolates are very virulent and the isolate MB11, PY12 is belonging to the classical strains of IBDV.

The HhaI enzyme digestion of PCR amplified product of VP2 gene variable region showed the presence of RE sites with different restriction profile for vaccine as well as field isolates of IBDV. Whereas Kataria et al. (1999) reported the presence of single RE site only in vaccine strains not in vvIBDV isolates. Shoshtari et al. (2004) reported that RT-
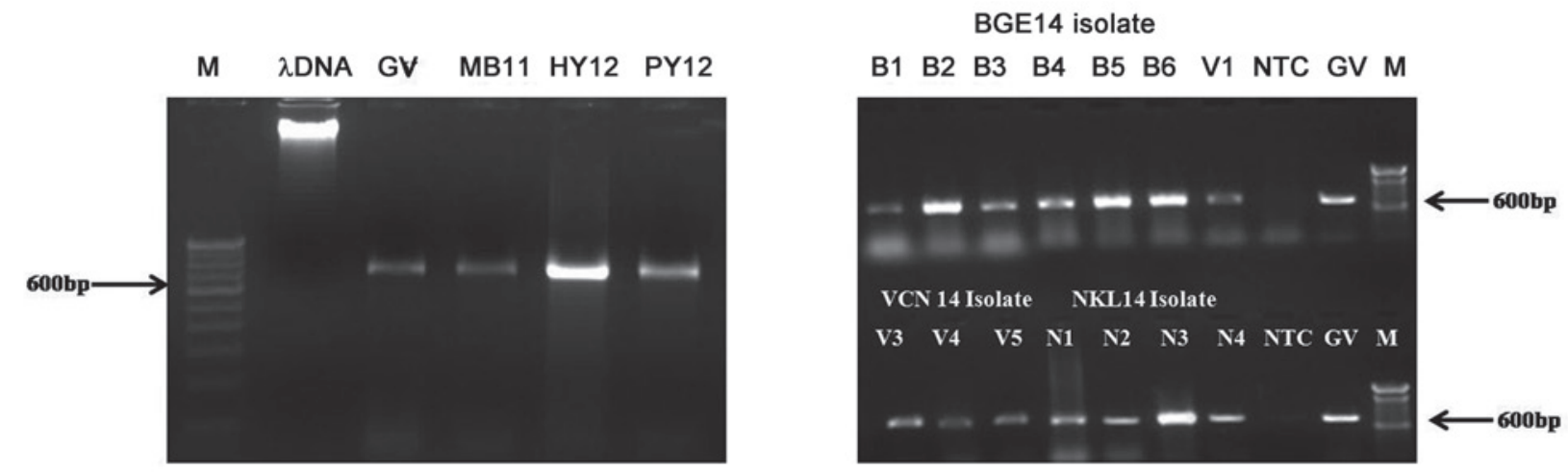

Fig. 5

BspMI digestion of RT-PCR amplified product of VP2 gene

The restriction profile pattern did not show any differences between the vaccine strain (GV) and other isolates. 

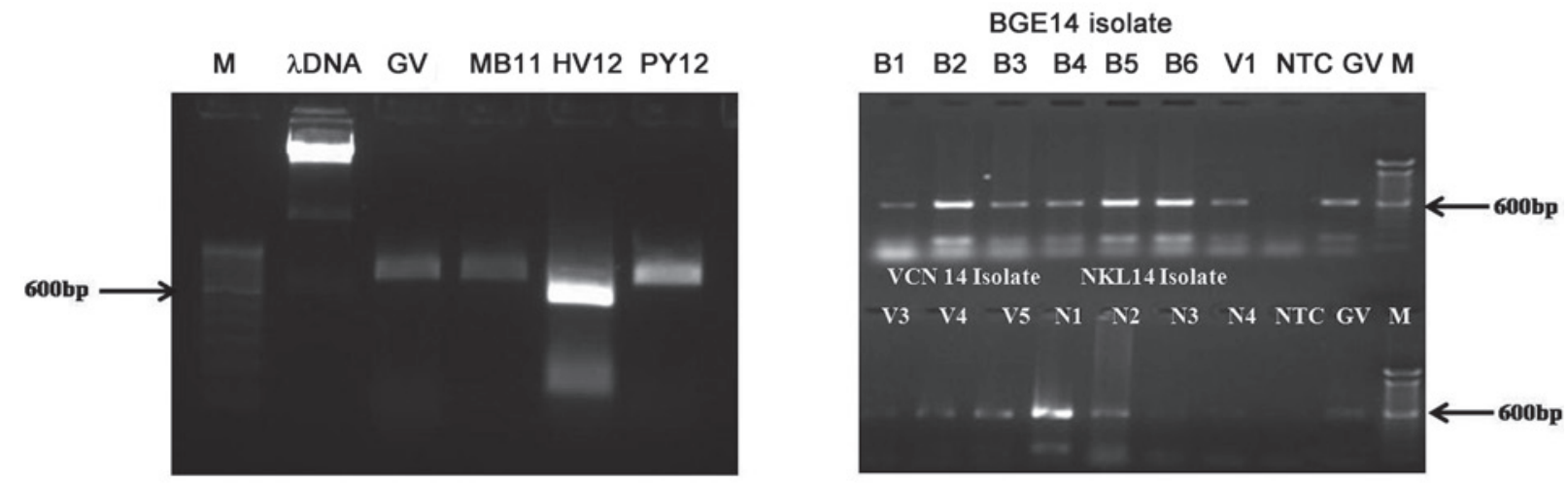

Fig. 6

StuI digestion of RT-PCR amplified product of VP2 gene

The restriction profile of vaccine strain (GV), MB11 and PY12 isolates revealed the absence of any restriction site, whereas BGE14, HY12, VCN14 and NKL14 isolates had a single restriction site.

PCR amplification and RE analysis of 643 bp fragment in VP2 gene of field classical and vaccine strains were cleaved with HhaI whereas very virulent field IBDV isolates were not cleaved. But in the present study, presence of HhaI site in the genome of vvIBDV is reported in Indian isolates and observed to produce different restriction profile among Indian isolates of vvIBDV. The isolates HY12, BGE14 and NKL14 showed differences in profile pattern among themselves and to the vaccine strain. From this study it was observed that HhaI enzyme was not an appropriate enzyme to differentiate the cvIBDV from vvIBDV.

Shoshtari et al. (2004) reported that SacI enzyme cleaved the PCR amplified products of field isolates of classical IBDV and vaccine strains. Whereas, in the present study, digestion of MB11, PY12 isolates with SacI showed the restriction profile similar to that of vaccine strain. But other field isolates were not cleaved by SacI, indicated the absence of SacI site in the 743 bp PCR amplified products belonging to the very virulent strains of IBDV. Loss of SacI RE site offered a rapid method of RFLP analysis and proved that RT-PCR/RFLP was simple and a sensitive method for detection of genetic variation among isolates that are closely related serologically. Our study is also in agreement with Sellers et al. (1999) and De Paula et al. (2004) that the SacI site is present only in cvIBDV. The SacI RE site might have been introduced into the genome of cvIBDV strain by silent mutation at the nucleotide position 867 (Zierenberg et al., 2001).

The SspI enzyme had a single RE site in the vvIBDV field isolates such as HY12, VCN14 and NKL14 whereas this site was absent in BGE14. But BGE14 was classified as vvIBDV with observations from other RE enzymes. The isolates MB11, PY12 and vaccine strain did not have site for SspI enzyme and indicated that they belonged to the cvIBDV. Our result was in accordance with Shoshtari et al. (2004) as they reported that only vvIBDV had single site for SspI enzyme. De Paula et al. (2004) reported that an amino acid substitution was observed in the SspI site in non-vvIBDV strains. Juneja et al. (2008) reported the presence of SspI restriction enzyme site in all the field isolates and not in vaccine strain (Lin et al., 1993; Hoque et al., 2001). The vvIBDV isolates,

Table 2. Differentiation of IBDV field isolates with different restriction enzymes and their restriction profile pattern

\begin{tabular}{|c|c|c|c|c|c|c|}
\hline \multirow{2}{*}{ IBDV isolates } & \multicolumn{5}{|c|}{ Restriction enzyme } & \multirow{2}{*}{$\begin{array}{l}\text { Classification } \\
\text { of isolates }\end{array}$} \\
\hline & HhaI & SacI & StuI & SspI & BspMI & \\
\hline Vaccine (Georgia) & + & + & - & - & + & Intermediate \\
\hline MB11 & + & + & - & - & + & Classical virulent \\
\hline HY12 & + & - & + & + & + & Very virulent \\
\hline PY12 & + & + & - & - & + & Classical virulent \\
\hline BGE14 & + & - & + & - & + & Very virulent \\
\hline VCN14 & + & - & + & + & + & Very virulent \\
\hline NKL14 & + & - & + & + & + & Very virulent \\
\hline
\end{tabular}

$(+)=\mathrm{IBDV}$ isolates are digested by the enzymes; $(-)=\mathrm{IBDV}$ isolates are not digested. 
88180 and HK46 did not have site for SspI (Eterradossi et al., 1999; Lim et al., 1999). Consequently, this SspI site was used as genetic marker to predict a vvIBDV. But Roussen et al. (2012) reported that all the vvIBDV strains do not have SspI site as marker and the SspI site is found in some nonvvIBDV strains also.

The RE digestion pattern with BspMI on hypervariable region of VP2 did not reveal any difference in the profile pattern among the isolates and the vaccine strain in the present study. According to Razmyar and Peighambari (2007), the $B s p M I$ digested only very virulent strains. Zierenberg et al. (2001) used BspMI analysis to compare serotype I (classical and vvIBDV) and serotype 2, in which the BspMI cleaved the vvIBDV except a West African strain, 88180 (vvIBDV) due to silent mutations. The BspMI cleavage site found in vvIBDV strains correlated with the amino acid position 222 (proline to alanine) in the major hydrophilic peak A of the VP2 hypervariable region. This amino acid exchange was conserved in all the vvIBDVs (Brown et al., 1994; Kataria et al., 2001).

The StuI enzyme did not digest MB11, PY12 and vaccine strain whereas the field isolates HY12, VCN14 and NKL14 were cleaved by this enzyme, indicating that these isolates belong to vvIBDV. Our results are also in correspondence with Shoshtari et al. (2004), who reported the presence of single RE site for StuI in vvIBDV. Juneja et al. (2008) also reported that $S t u I$ restriction site was present only in vvIBDV and not found in vaccine strains.

Acknowledgements. This work was supported by the Indian Council of Agricultural Research funding in the form of Niche area of Excellence on molecular diagnostics and vaccines for avian diseases [Grant No. 21141] in Animal Biotechnology.

\section{References}

Adamu J, Owoade AA, Abdu PA, Kazeem HM, Fatihu MY (2013): Characterization of field and vaccine infectious bursal disease viruses from Nigeria revealing viral VP2 subunit possible virulence and regional markers in the VP2 minor hydrophilic peaks. Avian Pathol. 42, 420-433. http:// dx.doi.org/10.1080/03079457.2013.822055

Balamurugan V, Kataria JM (2006): Economically important nononcogenic immunosuppressive viral diseases of chicken current status. Vet. Res. Commun. 30, 541-566. http:// dx.doi.org/10.1007/s11259-006-3278-4

Bayliss CD, Spies U. Shaw K. Peters RW, Papageorgiou A. Muller H, Boursnell MEG (1990): A comparison of the sequences of segment A of four infectious bursal disease virus strains and identification of a variable region in VP2. J. Gen. Virol. 71, 1303-1312. http://dx.doi.org/10.1099/00221317-71-6-1303

Becht H, Muller H, Muller HK (1988): Antigenic structure of the two serotypes of infectious bursal disease virus. J. Gen.
Virol. 69, 631-640. http://dx.doi.org/10.1099/0022-1317 -69-3-631

Brown MD, Green P, Skinner MA (1994): VP2 sequences of recent European "very virulent" isolates of infectious bursal virus are closely related to each other but are distinct from those of "classical" strains. J. Gen. Virol. 75, 675-680. http:// dx.doi.org/10.1099/0022-1317-75-3-675

Caston JR, Martinez-Torrecuadrada JL, Maraver A, Lombardo E, Rodriguez JF, Casal JI, Carrascosa JL (2001): C-terminus of IBDV major capsid protein VP2 is involved in definition of the number for capsid assembly. J. Virol. 75, 10815-10828. http://dx.doi.org/10.1128/JVI.75.22.10815-10828.2001

De Paula MBC, Yokosawa J, Coutinho, MDB (2004): Identification and molecular characterization of the infectious bursal disease virus (IBDV) from in outbreak in a broiler flock in midwestern Brazil. Braz. J. Microbiol. 35, 352-358. http:// dx.doi.org/10.1590/S1517-83822004000300016

Delmas BF, Kibenge SB, Leong JC, Mundt E, Vakharia VN, Wu JL (2005): Birnaviridae. In Fauquet CM, Mayo MA, Maniloff J, Desselberger U, LA Ball (Ed.): Virus Taxonomy. VIIIth Report of the International Committee on Taxonomy of Viruses. Elsevier / Academic Press, London, United Kingdom, pp. 561-569.

Dybing JK, Jackwood DJ (1996): Restriction analysis of MD infectious bursal disease virus strain. Avian Dis. 40, 931-937. http://dx.doi.org/10.2307/1592320

Eterradossi N, Arnauld C, Tekaia F, Toquin D, Le coq H, Rivallan G, Guittet M, Domenech J, Vanden berg TP, Skinner MA (1999): Antigenic and genetic relationships between European very virulent infectious bursal disease viruses and an early West African isolate. Avian Pathol. 28, 36-46. http://dx.doi.org/10.1080/03079459995028

Hoque MM, Omar AR, Chong LK, Hair-Bejo, M, Aini I (2001): Pathogenicity of SspI-positive infectious bursal disease virus and molecular characterization of the VP2 hypervariable region. Avian Pathol. 30, 369-380. http://dx.doi. org/10.1080/03079450120066377

Jackwood DJ, Nielsen CK (1997): Detection of restriction endonuclease assay. Infectious bursal disease viruses in commercially reared chickens using the reverse transcriptase/ polymerase chain reaction. Avian Dis. 41, 137-143. http:// dx.doi.org/10.2307/1592453

Jackwood DJ, Sommer-Wagner SE (2005): Molecular epidemiology of infectious bursal disease viruses: distribution and genetic analysis of newly emerging viruses in the United States. Avian Dis. 49, 220-226. http://dx.doi. org/10.1637/7289-101404R

Juneja SS, Ramneek, Deka D, Oberoi MS and Singh A (2008): Molecular characterization of field isolates and vaccine strains of infectious bursal disease virus. Comp. Immunol. Microbiol. Infect. Dis. 31, 11-23. http://dx.doi. org/10.1016/j.cimid.2007.03.001

Kataria RS, Tiwari AK, Butchaiah G, Kataria JM (1999): Differentiation of infectious bursal disease virus strains by restriction analysis of RT-PCR amplified VP2 gene sequences. Acta Virol. 43, 245-249.

Kataria RS, Tiwari AK, Butchaiah G, Kataria JM, Skinner MA (2001): Sequence analysis of the VP2 gene hyper- 
variable region of infectious bursal disease viruses from India. Avian Pathol. 30, 501-507. http://dx.doi. org/10.1080/03079450120078699

Kibenge FS, Dhillon AS, Russell RG (1988): Biochemistry and immunology of infectious bursal disease virus. J. Gen. Virol. 69, 1757-1775. http://dx.doi.org/10.1099/00221317-69-8-1757

Lim BL, Cao Y, Yu T, Mo CW (1999): Adaptation of very virulent IBDV to chicken embryonic fibroblasts by site-directed mutagenesis of residues 279 and 284 of viral coat protein VP2. J. Virol. 73, 2854-2862.

Lin Z, Kato A, Otaki Y, Nakamura T, Sasmaz E, Ueda S (1993): Sequence comparisons of highly virulent infectious bursal disease virus prevalent in Japan. Avian Dis. 37, 315-323. http://dx.doi.org/10.2307/1591655

Lukert PD, Saif YM (2003): Infectious bursal disease. In YM Saif, HJ Barnes, JR Gilsson, AM Fadly, LR McDougald, DE Swayne (Eds.): Disease of Poultry. 11th edn., Iowa state University Press, Ames, p.161-180.

Muller H, Islam MR, Raue R (2003): Research on infectious bursal disease. The past, the present, and the future. Vet. Microbiol. 97, 153-165. http://dx.doi.org/10.1016/j. vetmic.2003.08.005

Razmyar J, Peighambari SM (2007): Molecular characterization of Iranian infectious bursal disease viruses. Avian Dis. 52, 665-669. http://dx.doi.org/10.1637/8280-031008-Reg.1
Roussn DA, Al-Saleh W, Khawaldeh GY, Totanji WS (2012) Characterization of infectious bursal disease virus field strains in Jordan using molecular techniques - a short communication. Vet. Arhiv. 82, 115-124.

Sellers HS, Villegas PN, Seal BS, Jackwood DJ (1999): Antigenic and molecular characterization of three infectious bursal disease virus field isolates. Avian Dis. 43, 198-206. http:// dx.doi.org/10.2307/1592609

Shoshtari AH, Pourbakhsh SA, Dadras HA, Bahmaninejad MA, Toroghi R (2004): Pathogenicity study and restriction enzyme profile of a recently isolated infectious bursal disease virus in Iran. Arch. Razi Ins. 58, 9-18.

Ture O, Saif YM, Jackwood DJ (1998): Restriction fragment length polymorphism analysis of highly virulent strains of infectious bursal disease viruses from Holland, Turkey and Taiwan. Avian Dis. 42, 470-479. http://dx.doi. org/10.2307/1592673

Winterfield RW, Fadly AM, Bickford A (1972): Infectivity and distribution of infectious bursal disease virus in the chicken: Persistence of the virus and lesions. Avian Dis. 16, 622-632. http://dx.doi.org/10.2307/1588678

Zierenberg K, Raue R, Muller H (2001): Rapid identification of very virulent strains of infectious bursal disease virus by reverse transcriptase-polymerase chain reaction combined with restriction enzyme analysis. Avian Pathol. 30, 55-62. http://dx.doi.org/10.1080/03079450020023203 